\title{
Management of spinal trauma in emergency department
}

\author{
Hızır Ufuk Akdemir ${ }^{\text {a* }}$, Celal Katı ${ }^{\mathrm{a}}$, Latif Duran ${ }^{\mathrm{a}}$, Enis Kuruoğlu ${ }^{\mathrm{b}}$ \\ ${ }^{a}$ Department of Emergency Medicine, Faculty of Medicine, Ondokuz, Mayls University, Samsun, Turkey \\ ${ }^{b}$ Department of Neurosurgery, Faculty of Medicine, Ondokuz Mayıs University, Samsun, Turkey
}

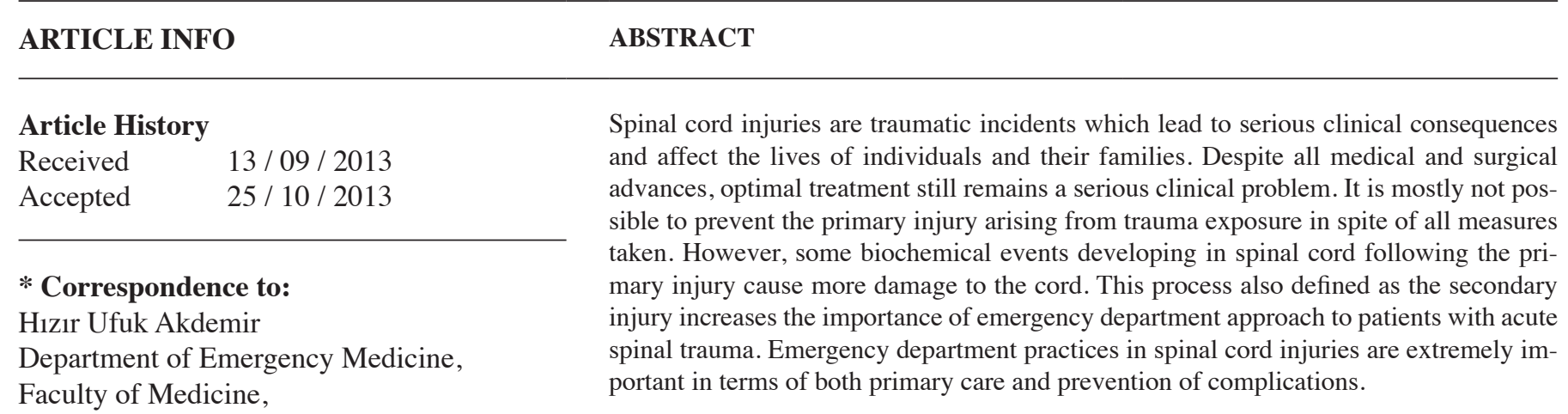

Ondokuz Mayıs University,

Samsun, Turkey

J. Exp. Clin. Med., 2013; 30:285-289

e-mail: hufukakdemir@hotmail.com

\section{Keywords:}

Emergency department

Management

Spinal cord

Trauma

\section{Introduction}

Spinal cord injuries (SCI) are injuries with a high clinical importance due to serious resulting consequences. Acute spinal cord injuries occur at a rate of 2-4/100.000 in many countries. The annual incidence of SCI ranges between 7500-10.000 ( $\mathrm{Li}$ et al., 2000; Baron et al., 2011). SCI occurs most often between the ages of 16 and 30. Motor vehicle accidents (40\%), acts of violence $(25 \%)$ falls $(20 \%)$ and sports accidents (5$10 \%$ ) are prominent causes in the United States (Raineteau and Schwab, 2001; Baron et al., 2011). The rates of sports accidents in European countries are higher while injuries associated with acts of violence are less common (Raineteau and Schwab, 2001). The rate of spinal cord injuries in our country is $1.2 / 100.000$ and the annual incidence is reported to be 500600 cases. It is reported that the male/female rate ratio is $4 / 1$ and the most common cause of spinal cord injuries is motor vehicle accidents (48.8\%) (Dryden et al., 2003). Almost two of three spinal injuries occur in cervical spine (Fehlings et al., 2001). Today there is no effective medical treatment agent to preserve neurological function in patients with complete injury, except for methylprednisolone (Bracken et al., 1984; Tator and Fehlings, 1991; Hurlbert, 2000). Depending on the actions such as timely and properly rendered first aid, better resuscitation and fastening seat belts, the incidence of complete spinal cord injuries has decreased. All such factors positively influence recovery process (Tator, 2002).

\section{Patient Management}

In acute SCI, patient management involves airway, respiratory and oxygenation protection and maintaining optimal blood pressure by controlling blood loss as well as early mechanical and surgical stabilization (Stahel et al., 2012). Unstable injuries with neurological signs require urgent treatment. If a patient has no neurological signs, the process of diagnosis 
and treatment should be guided taking into consideration the mechanism of injury due to the exposure to force. In doubt, further examination and treatment is the most appropriate choice in order not to overlook a major injury (Schouten et al., 2012). As in the approach to all trauma patients, first of all a fast primary assessment should be performed on any patient with spinal cord injury or suspected of having spinal injury. The first thing to do is to ensure that patient has an open airway and restore respiratory and circulatory parameters. The presence of a second life-threatening injury should be quickly assessed. Patients with spinal injury or suspected of having spinal injury should be transported on backboards after ensuring adequate cervical spine immobilization (Kortbeek et al., 2008; Stahel et al., 2012).

\section{1. Diagnostic evaluation of spinal cord injuries}

Sufficiently understanding patients in acute SCI depends on optimal clinical examination, neurological damage classification, and detailed radiological evaluation of spinal damage (Kaptanoğlu et al., 2005). The best classification method in SCI is the classification based on clinical assessment and determination of functional neurological damage (Maynard et al., 1997). ASIA/IMSOP Classification has provided a unity and harmony in terms of neurological and functional reviews of physicians about patients with spinal cord injury (Maynard et al., 1997; Kaptanoğlu et al., 2005) (Table 1). A physical examination properly carried out can lead a physician to a specific conclusion regarding spinal injury. A patient's four extremities should be carefully evaluated in terms of motor, sensory, and reflexes. The presence of tenderness, swelling, digit deformity and crepitus should be evaluated through the palpation of the spine. Hypotension, bradycardia and warm tachycardia extremities should be associated with neurogenic or spinal shock due to spinal cord injury while hypotension, tachycardia and cold extremities should be associated with hypovolemic (hemorrhagic) shock (Kaptanoğlu et al., 2005).

\section{2. Radiological diagnostic methods in spinal cord injuries}

In patients suspected of having spinal cord injury, plain radiographs are essential for initial radiological evaluation (Bradley, 2008).

\section{Plain radiographs of the cervical spine}

Evaluation of cervical spine by plain radiography is often a standard practice in blunt trauma. The cervical spine of unconscious patients with head or neck trauma (Glasgow Coma Scale score <15) must be viewed (Bayless and Ray, 1989). Many trauma centres recommend that in all trauma patients, plain radiographs of the spine be taken in all positions (anteroposterior, lateral and open mouth odontoid radiograph) (Bradley, 2008). It is necessary to view the seven cervical vertebrae including the junction of the seventh cervical vertebra and first thoracic vertebra. Lateral plain radiographs are the initial practices of spinal trauma examination. The top of $\mathrm{T} 1$ vertebral body must be visible on lateral radiographs. Arm traction and swimming position can be used, if the corpus of the T1 vertebra is not precisely evaluated, (Bradley, 2008; Baron et al., 2011). Oblique radiographs are effective methods in the evaluation of facet joints and foramina, but are not included in the standard evaluation (Bradley, 2008). Open mouth odontoid view often reveals many abnormalities. The National Emergency X-Radiography Utilization Study (NEXUS) established five criteria (no tenderness at the posterior midline of the cervical spine, normal level of alertness, no evidence of intoxication, no focal neurologic deficit, and no clinically apparent painful distracting injury) to assess the use of plain cervical radiographs (Hoffman et al., 2000). Active use of these criteria in clinical practice is highly useful in terms of the standardization of plain cervical radiographs.

\section{Plain radiographs of the thoracolumbar spine}

Principles used in the cervical spine imaging also apply to the thoracic and lumbar spine imaging. Patients with dorsalgia and/or tenderness identified by physical examination should be considered as if there are fractures in the thoracic or lumbar region, and immobilization should be ensured. Anteroposterior and lateral radiographs are usually sufficient to detect pathologies. Lateral radiographs are usually easier to be taken in patients lying on backboards. Even if x-rays are used to the maximum in order to view the upper thoracic spine, radiography quality may not be as desired. The alternative is to conduct good physical and neurological examination on patients. Patients with normal plain radiographs and point tenderness identified by physical examination should be scanned by computed tomography (CT) (Baron et al., 2011).

\section{Computed tomography}

In the diagnosis of acute SCI, CT is the most useful imaging technique as it is a cheap and quick method. CT is the most sensitive imaging method in the assessment of spine layout, fracture pattern and the spinal canal integrity. It is also able to detect the epidural and subdural hematomas (Bradley, 2008). In addition to images in the axial plane, it also allows imagining in the coronal and sagittal planes through reconstruction. The need to transport patients to the CT scanner and the inability to transfer unstable patients to examination room are the disadvantages of CT. CT is inadequate for evaluating soft tissues, thus its efficiency is low in the detection of spinal cord, disc and ligament damages. The use of CT together with plain radiographs provides the optimum result. CT provides many benefits in the evaluation of regions such as the cervicothoracic junction and the thoracic spine which are hard to

\section{Table 1. ASIA-IMSOP Impairment Scale (Tator and Fehlings, 1991; Maynard et al., 1997)}

Grade A Complete

Grade B Incomplete

Grade C Incomplete

Grade D Incomplete

Grade E Normal
No motor or sensory function is preserved in the sacral segments S4-S5.

Sensory but not motor function is preserved below the neurological level and the injury includes the sacral segments S4-S5. Motor function is preserved below the neurological level and more than half of key muscles below the neurological level have a muscle grade of less than 3 .

Motor function is preserved below the neurological level and at least half of the key muscles below the neurological level have a muscle grade of 3 or more.

Normal motor and sensory function 
be evaluated on plain radiographs. (CT) is also the best imaging method for the evaluation of vertically localized fractures (Bradley, 2008). CT is one of the advanced imaging methods to be used in patients with persistent pain and symptoms localized in spinal segments.

\section{Magnetic resonance imaging}

There is an indication for the use of MRI in patients with post-traumatic neurological signs and symptoms (Is and Safak, 2005). MRI is perfect to show soft tissue injuries. Traumatic disc hernias and spinal cord contusions are easily demonstrated by MRI. It is an important examination in terms of early diagnosis and treatment planning. MRI can also be used in the evaluation of ligament lesions (Hall et al., 1993). MRI may help shed light on the clinical picture in SCI patients whose neurological findings cannot be explained by plain radiographs and CT.

\section{Emergency approach in spinal cord injuries Pre-hospital period}

The main points of pre-hospital care in SCI are protection of airway patency, restoring respiration, initiation of fluid therapy and spinal immobilization (Stahel et al., 2012). Primarily, hypoxia and hypercapnia should be prevented in order to minimize the damage and protect neural tissue; and volume replacement is required to prevent tissue hypoxia. Until proven otherwise, patients with neck and back pain or tenderness should be considered as if there is spinal and/or spinal cord injury (Baron et al. 2011; Stahel et al., 2012). Cervical spine should be stabilized with a rigid cervical collar and supported by tape or sandbags. Transport can be provided by immobilizing thoracic and lumbar spine with long backboards. However, many centres try to limit the use of such stabilizers to two hours (Bradley, 2008). Besides being uncomfortable, backboards may result in the development of life-threatening complications which may disrupt the quality of life of patients such as decubitus ulcers. All the effort is to quickly transport patients to a spine/spinal cord treatment centre. As a general rule, hemodynamically unstable patients should be transported to the nearest hospital.

\section{Stabilization in the emergency department Airway}

Even if patients with cervical spinal cord injury are stable in the primary examination, one should be on the alert for airway control. The higher level of the spinal injury is, the sooner advanced airway opening should be considered (Baron et al., 2011). Patients with lesions on the fifth cervical vertebra $\left(\mathrm{C}_{5}\right)$ may need respiratory support in the following period as a result of phrenic nerve involvement-linked diaphragmatic paralysis. For such patients, early intubation is recommended. During intubation, hyperextension must be avoided in order not to cause more damage in the spine (Berker, 2004). The cervical spine must be stabilized during airway opening. Orotracheal intubation must be performed generally by stabilizing the cervical spine and pressing the cricoids. Oxygen can be delivered by nasal cannula, mask, oropharyngeal airway or endotracheal tube (Berker, 2004). Patients can be monitored by placing fingertip pulse oximetry probe in terms of oxygen saturation. Nasal intubation can be done in order to ensure spinal immobilization; however, nasal intubation usually is not preferred as it is a blind technique. All patients with spinal cord trauma should be sedated before nasal intubation (Baron et al., 2011). In patients with severely impaired breathing pattern, nasotracheal intubation may not be applicable. An unwanted spinal movement may worsen an unstable fracture. The diameter of tubes used for intubation of patients should measure enough to maintain an open airway during hospitalization. Tracheotomy or needle cricothyroidotomy may be required in patients with severe airway injury and oedema (Bradley, 2008).

\section{Hypotension}

Hemodynamic stability should be ensured immediately after airway stabilization. Hypotension is common in patients with SCI. However, the causes of hypotension are variable; and it may sometimes be due to SCI and sometimes due to blood loss or cardiac damage (Baron et al., 2011). Lesions on the sixth thoracic vertebra form functional sympathectomy-like syndrome due to affected cardiac accelerator nerves (Kiriş and Görgülü, 2005). Adrenergic tonus disappears, and dilation occurs in arteries and veins. Relative hypovolemia occurs due to venous congestion (Berker, 2004). One should always remember that spinal and/or neurogenic shock may develop in these patients and should know that vital signs may be nonspecific from time to time. Even if hemorrhagic shock develops in patients with spinal injury in neurogenic shock, expected tachycardia does not occur. Thus, in all trauma patients, hypotension should primarily be associated with blood loss, unless proven otherwise

In hypotensive blunt trauma patients, factors other than SCI are less effective while the cause of hypotension is blood loss in more than $90 \%$ of patients with penetrating spinal cord injury. In spinal fractures, bleeding on the second lumbar artery should be considered especially in patients with a history of fall from height. In each patient with spinal fractures, one should be careful of possible damage to intra-abdominal organs and rigorously perform an abdominal examination. In hemodynamically unstable patients, the use of bedside ultrasonography or diagnostic peritoneal lavage (DPL) is recommended instead of CT (Baron et al., 2011).

Patients with acute SCI who do not respond to volume replacement should be evaluated in terms of spinal shock and autonomic dysfunction (Bradley, 2008). Through intravenous volume replacement, systolic blood pressure should be kept around 80 to $100 \mathrm{mmHg}$. When pulse rate drops below 40 beats per minute, there is an indication for atropine use. In patients over the age of fifty, Swan-Ganz catheterization should be performed and the pulmonary capillary wedge pressure (PCWP) should be kept around $18 \mathrm{mmHg}$. When hypotension cannot be treated by volume replacement, vasopressor agents such as dopamine and dobutamine may be used (Berker, 2004; Kiriş and Görgülü, 2005).

\section{Neurological examination}

In physical examination, the presence of neck and/or back tenderness should be examined, detailed neurological examination must be performed and findings should be recorded. The strength of each muscle group should be assessed by grading from 0 to 5 (Baron et al., 2011). The level of sensory loss should be determined; and functions of vibration and proprioception should be checked in order to evaluate 
the functions of posterior column. Deep tendon reflexes and anogenital reflex should also be checked, since in patients with complete sensory and motor loss, sacral recovery in the presence of reflexes indicates incomplete SCI (Baron et al., 2011). Simultaneous contraction of the anal sphincters is checked by squeezing the glans penis, thus bulbocavernosus reflex is tested (Kaptanoğlu et al., 2005). In this way, the rectal tonus is also evaluated. Cremasteric reflex is checked by stroking the inner thigh with a blunt object or needle. If the scrotum draws up, it may be considered that a portion of the spinal cord remains intact (Kaptanoğlu et al., 2005). The area around the anus is checked by examining with a needle, and the contraction of the anal sphincter muscles indicates partial sacral recovery (Baron et al., 2011). If a patient needs to be rolled during examination, the "logrolling" method typically requiring a minimum of four persons should be used. One person keeps the head in the same plane with the body with slight traction while two other persons are stabilizing the body and the fourth person is examining the patient (Bradley, 2008). This enables the immobilization of the patient with SCI or suspected of having SCI.

\section{Methylprednisolone}

In the last 30 years, several experimental and clinical studies have been conducted for the treatment of secondary SCI with various steroids or steroid-containing compounds (Kiriş and Görgülü, 2005). Just as there are publications advocating the inefficiency of glucocorticoids in acute SCI, there are also other publications indicating that high-dose methylprednisolone improves neurologic status. The initial use of corticosteroids is associated with its effect of reducing spinal cord oedema and its anti-inflammatory properties. The effect of methylprednisolone in reducing spinal cord damage is considered to depend on many mechanisms. These are inhibition of lipid peroxidation, prevention of progressive post-traumatic ischemia through the regulation of tissue blood flow and aerobic energy metabolism, inhibition of neurofilament degradation, prevention of intracellular calcium accumulation, inhibition of prostaglandin F2-alpha and thromboxane A2 formation, and reduction of spinal neuronal excitability (Dumont et al., 2001; Topsakal et al., 2002).

In completed nine clinical trials on SCI, steroid therapy was used. These are NASCIS- National Acute Spinal Cord Injury Study-I (Bracken, 1984), NASCIS II (Bracken, 1990) and NASCIS III (Bracken, 1998), and studies of Kiwerski (1993), Otani (1994), Prendergast (1994), George (1995), Poynton (1997) and Pointillart (2000). Considering the results of these nine clinical trials on steroids, only two (NASCIS II, III) revealed that steroids offered benefits (Bracken et al., 1984; Bracken et al., 1990; Bracken et al., 1992).

Despite intensive efforts, the chain of events which occur in the early stage of SCI and have serious influence in the injury process has not yet been fully elucidated. No effective medical treatment other than the possible effects of methylprednisolone has been found to restore neurological function in patients with complete SCI (Bracken et al., 1990; Zileli, 1997). Methylprednisolone is a synthetic glucocorticoid and used for a long time in patients with SCI (Zileli, 1997). Methylprednisolone has been shown to lead to significant improvement in both motor and sensory functions (Bracken et al., 1990). Methylprednisolone infusion restores motor and sensory loss in patients with complete and incomplete SCI. This expected positive outcome depends on the use of steroid at the right time at the right dose (Baron et al., 2011).

In humans, it is suggested to give methylprednisolone as $30 \mathrm{mg} / \mathrm{kg}$ bolus over 15 minutes. Methylprednisolone intravenous infusion is continued following a 45 -minute pause for 23 hours. Total time is 24 hours and treatment should be initiated within the first 8 hours of injury (Baron et al., 2011). Prolonged corticosteroid therapy which exceeds 48 hours is not recommended (Kiriş and Görgülü, 2005). The effectiveness of this treatment has been tried in blunt and closed injuries, and corticosteroids are not used in penetrating traumas (Kaptanoğlu et al., 2005; Kiriş and Görgülü 2005; Baron et al., 2011). Methylprednisolone treatment should be extended to 48 hours in patients admitted between 3-8 hours after injury. Methylprednisolone treatment should not be administered to patients admitted later than 8 hours (Bracken et al., 1984; Bracken et al., 1992; Maynard et al., 1997; Bracken et al., 1998).

Common complications of prolonged or high-dose treatment with methylprednisolone are pneumonia, sepsis, wound infection, thromboembolism, gastrointestinal bleeding and delayed healing (Baron et al., 2011).

\section{Surgical treatment in SCI}

There are two objectives in the surgical treatment of acute SCI. The first is decompression of neural structures and the second is spinal stabilization (Bradley, 2008). The role and timing of surgical treatment in patients with acute spinal cord injury is still being debated. NASCIS II revealed that the results obtained in the patients undergoing surgery in the acute phase ( $<25$ hours) were better than in those who did not undergo surgery (Bracken et al., 1990, Bracken et al., 1992; Maynard et al., 1997). Early surgical intervention is recommended by many specialists (Waters et al., 1999; Kiriş and Görgülü, 2005). However, a group of specialists express the opinion that patients with acute SCI need to receive medical treatment for a week or longer in order to ensure systemic and neurological stabilization. The increasing rate of complications in early surgery is given as a reason for this opinion (Waters et al., 1999).

\section{REFERENCES}

Baron, B.J., McSherry, K.J., Larson, J.L., Scalea,T.M., 2011. Spine and spinal cord trauma. In Tintinalli's Emergency Medicine. A Comprehensive Study Guide. Chapter 255. Judith, E., Tintinalli, J.S., Stapczynski, D.M., Cline, O.J., Ma, R.K., Cydulka, G.D., Meckler, eds. McGraw-Hill. New York, pp. 1569-1582.

Bayless, P., Ray, V.G., 1989. Incidence of cervical spine injuries in association with blunt head trauma. Am. J. Emerg. Med. 7, 139-142.

Berker, M., 2004. Spinal kord yaralanmaları. Yoğun Bakım Dergisi 4, 220-226.

Bracken, M.B., Collins, W.F., Freeman, D.F., Shepard, M.J., Wagner, F.W., Silten, R.M., Hellenbrand, K.G., Ransohoff, J., Hunt, W.E., Perot, P.L., 1984. Efficacy of methylprednisolone in acute spinal cord injury. JAMA. 251, 45-52.

Bracken, M.B., Shepard, M.J., Collins, W.F., Holford, T.R., Baskin, D.S., Eisenberg, H.M., Flamm, E., Leo-Summers, L., Maroon, J.C., Marshall, 
L.F., 1992. Methylprednisolone or naloxone treatment after acute spinal cord injury: 1-year follow-up data. Results of the second national acute spinal cord injury study. J. Neurosurg. 76, 23-31.

Bracken, M.B., Shepard, M.J., Collins, W.F., Holford, T.R., Young, W., Baskin, D.S., Eisenberg, H.M., Flamm, E., Leo-Summers, L., Maroon, J., 1990. A randomized, controlled trial of methylprednisolone or naloxone in the treatment of acute spinal-cord injury. Results of the second national acute spinal cord injury study. N. Engl. J. Med. 322, 1405-1411.

Bracken, M.B., Shepard, M.J., Holford, T.R., Leo-Summers, L., Aldrich, E.F., Fazl, M., Fehlings, M.G., Herr, D.L., Hitchon, P.W., Marshall, L.F., Nockels, R.P., Pascale, V., Perot, P.L., Piepmeier, J., Sonntag, V.K., Wagner, F., Wilberger, J.E., Winn, H.R., Young, W., 1998. Methylprednisolone or tirilazad mesylate administration after acute spinal cord injury: 1-year follow up. Results of the third national acute spinal cord injury randomized controlled trial. J. Neurosurg. 89, 699-706.

Bradley, W.G., 2008. Sinir sistemi travması, spinal kord travması. In neurology in clinical practice. Tan, E., Özdamar, S.E,. eds. Veri Medikal Yayınc1lı, İstanbul, pp. 1115-1144.

Dryden, D.M., Saunders, L.D., Rowe, B.H., May, L.A., Yiannakoulias, N., Svenson, L.W., Schopflocher, D.P., Voaklander, D.C, 2003. The epidemiology of traumatic spinal cord injury in Alberta, Canada. Can. J. Neurol. Sci. 30, 113-121.

Dumont, R.J., Verma, S., Okonkwo, D.O., Hurlbert, R.J., Boulos, P.T., Ellegala, D.B., Dumont, A.S., 2001. Acute spinal cord injury, part II: Contemporary pharmacotherapy. Clin. Neuropharmacol. 24, 265-279.

Fehlings, M.G., Sekhon, L.H., Tator, C., 2001. The role and timing of decompression in acute spinal cord injury: What do we know? What should we do? Spine. 26, 101-110.

George, E.R., Scholten, D.J., Buechler, C.M., Jordan-Tibbs, J., Mattice, C., Albrecht, R.M., 1995. Failure of methylprednisolone to improve the outcome of spinal cord injuries. Am Surg. 61, 659-663.

Hall, A.J., Wagle, V.G., Raycroft, J., Goldman, R.L., Butler, A.R., 1993. Magnetic resonance imaging in cervical spine trauma. J. Trauma. 4, $21-26$.

Hoffman, J.R., Mower, W.R., Wolfson, A.B., Todd, K.H., Zucker, M.I., 2000. Validity of a set of clinical criteria to rule out injury to the cervical spine in patients with blunt trauma. National Emergency X-Radiography Utilization Study Group. Engl. J. Med. 343, 94-99.

Hurlbert, R.J., 2000. Methylprednisolone for acute spinal cord injury: An inappropriate standard of care. J. Neurosurg. 93, 1-7.

Is, M., Safak, A.A., 2005. Servikal omurga yaralanmalarında tanı görüntüleme yöntemleri. Düzce Tıp Fakültesi Dergisi. 1, 35-42.

Kaptanoğlu, E., Torun, F., Atar A., 2005. Spinal travma. In Temel Nöroşirurji, Volume 2.Aksoy, K., Paloğlu, S., Pamir, N., Tuncer, R., Eds. Türk Nöroşirurji Derneği Yayınları, Ankara, pp. 1144-1231.

Kiriş, T., Görgülü, A., 2005. Omurilik travmaları. In Travma, Ertekin, C. , Taviloğlu, K., Güloğlu, R., Kurtoğlu, M., Eds. İstanbul Medikal Yayıncilık, İstanbul, pp. 805-818.

Kiwerski, J.E., 1993. Application of dexamethasone in the treatment of acute spinal cord injury. Injury. 24, 457-460.

Kortbeek, J.B., Al Turki, S.A., Ali, J., Antoine, J.A., Bouillon, B., Brasel, K., Brenneman, F., Brink, P.R., 2008. Advanced trauma life support, 8th edition, the evidence for change. J. Trauma. 64, 1638-1650.

Maynard, F.M., Bracken, M.B., Creasey, G., Ditunno, J.F., Donovan, W.H., Ducker, T.B., Garber, S.L., Marino, R.J., Stover, S.L., Tator, C.H., Waters, R.L., Wilberger, J.E., Young, W., 1997. International Standards for neurological and functional classification of spinal cord injury. American Spinal Injury Association. Spinal Cord. 35, 266-274.

Otani, T., Kai, S., Narushima, M., 1994. Ejaculation obtained by intracavernous papaverine in a cervical spinal cord injury patient resulting in pregnancy and childbirth. Case report. Paraplegia. 32, 180-181.

Pointillart, V., Petitjean, M.E., Wiart, L., Vital, J.M., Lassié, P., Thicoipé, M., Dabadie, P., 2000. Pharmacological therapy of spinal cord injury during the acute phase. Spinal Cord. 38, 71-76.

Poynton, A.R., O'Farrell, D.A., Shannon, F., Murray, P., McManus, F., Walsh, M.G., 1997. An evaluation of the factors affecting neurological recovery following spinal cord injury. Injury. 28, 545-548.

Prendergast, M.R., Saxe, J.M., Ledgerwood, A.M., Lucas, C.E., Lucas, W.F., 1994. Massive steroids do not reduce the zone of injury after penetrating spinal cord injury. J. Trauma. 37, 576-579.

Raineteau, O., Schwab, M.E., 2001. Plasticity of motor systems after incomplete spinal cord injury. Nat. Rev. Neurosci. 2 , $263-273$.

Schouten, R., Albert, T., Kwon, B.K., 2012. The spine-injured patient: Initial assessment and emergency treatment. J. Am. Acad. Orthop. Surg. 20,336-346.

Stahel, P.F., VanderHeiden, T., Finn, M.A., 2012. Management strategies for acute spinal cord injury: Current options and future perspectives. Curr. Opin. Crit. Care. 18, 651-660.

Tator, C.H., 2002. Strategies for recovery and regeneration after brain and spinal cord injury. Inj. Prev. 8, 33-36.

Tator, C.H., Fehlings, M.G., 1991. Review of the secondary injury theory of acute spinal cord trauma with emphasis on vascular mechanisms. J. Neurosurg. 75, 15-26.

Topsakal, C., Erol, F.S., Ozveren, M.F., Yilmaz, N., Ilhan, N., 2002. Effects of methylprednisolone and dextromethorphan on lipid peroxidation in an experimental model of spinal cord injury. Neurosurg. Rev. 25, 258-266.

Waters, R.L, Meyer, P.R., Adkins, R.H., Felton, D., 1999. Emergency, acute, and surgical management of spine trauma. Arch. Phys. Med. Rehabil. 80, 1383-1390.

Zileli, M., 1997. Omurilik yaralanmasının farmakolojik tedavisi. In Omurilik ve Omurga Cerrahisi, Zileli, M., Özer, F., Eds. Saray Medikal Yayınc1lı, İzmir, pp. 466- 478. 